\title{
Influence of Capital Structure on Firm Performance: Evidence from Bangladesh
}

\author{
Md. Bokhtiar Hasan ${ }^{1}$, A. F. M. Mainul Ahsan², Md. Afzalur Rahaman ${ }^{3} \&$ Md. Nurul Alam ${ }^{4}$ \\ ${ }^{1}$ Department of Finance and Banking, Islami University, Kushtia, Bangladesh \\ ${ }^{2}$ Department of Economics, School of Business, Independent University, Bangladesh (IUB), Bangladesh \\ ${ }^{3}$ Research, Development \& Information Department, Dhaka Stock Exchange Limited, Bangladesh \\ ${ }^{4}$ The University of Sydney, Business School, Australia \\ Correspondenc: Md. Nurul Alam, The University of Sydney, Business School, Australia. E-mail: \\ alam_finance@yahoo.com
}

Received: Decemeber 27, 2013

Accepted: March 5, $2014 \quad$ Online Published: April 18, 2014

doi:10.5539/ijbm.v9n5p184

URL: http://dx.doi.org/10.5539/ijbm.v9n5p184

\begin{abstract}
This paper mainly studies the influence of capital structure on firm's performance. This investigation has been performed on a sample of 36 Bangladeshi firms listed in Dhaka Stock Exchange during the period 2007-2012. We have used four performance measures; earnings per share (EPS), return on equity (ROE), return of asset (ROA) and Tobin's Q; as dependent variables and three capital structure ratios; short-term debt, long-term debt and total debt ratios; as independent variables. Using pooling panel data regression method, we found that EPS is significantly positively related to short-term debt while significantly negatively related to long-term debt. There is significant negative relation between ROA and capital structure. On the other hand, there is no statistically significant relation exists between capital structure and firm's performance as measured by ROE and Tobin's Q. Nonetheless, aside from the positive relation between EPS and STDTA, we can conclude that capital structure has negative impact on firm's performance which is consistent with the proposition of Pecking Order Theory.
\end{abstract}

Keywords: capital structure, firm performance, panel data

\section{Introduction}

Capital structure is the combination of a firm's long-term debt, specific short-term debt, common equity, preferred equity and retained earnings which are used to finance its overall operations and growth. Capital structure is a very important financial decision as it is directly related to the risk and return of a firm. Any immature capital structure decision can result in high cost of capital; thereby lowering firm's value while effective capital structure decision can do the opposite. Some scholars also defined capital structure in their own ways. The term 'capital structure' is defined by Weston and Brigham (1979) as the permanent financing of the firm represented by long-term debt, preferred stock and net worth. According to Van Horne and Wachowicz (1995), capital structure is the mix of a firm's permanent long-term financing represented by debt, preferred stock, and common stock equity. From the above discussion, it is clear that capital structure combines mainly equity and long-term debt. Traditionally capital structure does not consider short-term debt, but in our study we do consider it.

Since many years, both researchers and academicians are performing theoretical and empirical studies on capital structure, but it drew attention to the financial economists after Modigliani and Miller's (1958) "irrelevance theory of capital structure" (hereafter referred to as MM theory). All researches suggests that there is an optimal capital structure; the one that maximizes the value of the firm and simultaneously minimizes the cost of capital thus striking a balance between risk and return. However, it is not yet possible to provide financial managers with a precise methodology for determining a firm's optimal capital structure (Gitman \& Zutter, 2010). After MM propositions, many studies were focused in finding the optimal capital structure. Even though MM theory is based on some unrealistic assumptions, for instance, the assumption of perfect capital markets, this theory provides us a basis to perform research on capital structure. Hitherto four major theories of capital structure emerged; such as the trade-off theory, agency costs theory, pecking order theory, and market timing theory. 
According to Modigliani and Miller (1958), under perfect capital markets assumption, the capital structure has no impact on firm's value. This theory is criticized by many researchers objecting that there are no perfect capital markets in reality, although later they revised their earlier theory by incorporating tax benefit and argued that under market imperfection where interest payments are tax deductible, firm value will increase with the level of financial leverage (Modigliani \& Miller, 1963).

The trade-off theory argues that firms trade off the benefits and costs of debt and equity financing and reach to an optimal capital structure even with the market imperfections such as taxes, bankruptcy costs and agency costs. Profitable firms can borrow more up to a certain level, because after that the profitability and the value of the firm will decrease due to interaction of bankruptcy costs and agency costs. However, to expand the MM theory, Jensen and Meckling (1976) developed agency costs theory. According to agency costs theory, the agency problem is caused by a conflict of interest between shareholders and managers (agency cost of equity) or between shareholders and debt holders (agency cost of debt). Thus, the use of debt will reduce the agency cost since the payment of interest reduces the surplus cash (Suleiman, 2013).

In contrast to trade-off theory, Myers and Majluf (1984) introduced the pecking order theory which articulates that optimal capital structure does not exist. They argued that to minimize the problem of asymmetric information between firms' managers and investors, financial pecking order; i. e. a hierarchy of financing that begins with retained earnings, which is followed by debt, and finally new stock issues, takes place. Recently, Baker and Wurgler (2002) have recommended a new theory of capital structure; "market timing theory of capital structure" which suggests that managers can increase current shareholder's wealth by timing the issue of securities. Therefore, firms time their equity issues by selling new stocks when the stock price is perceived to be overvalued, and buying back own shares when they are undervalued.

From the above discussion, one important thing is obvious that the basic drive of all the theories of capital structure is to recognize whether the capital structure has any impact on firm's performance or not. Extensive empirical researches have been performed to study the relationship between capital structure and firm's performance although Bangladesh has very little contribution in this literature. Therefore, this effort is attempted by us. However, this study aims to examine the relationship between capital structure choices and firm's performance employing a sample of 36 firms listed in Dhaka Stock Exchange for the period 2007-2012. Applying panel data regression analysis, we found mixed result about the relation between them.

The rest of the paper is therefore arranged as below: Part 2 discusses the previous literature. Part 3 focuses on Methodology and data. Part 4 presents the result analysis of this research, and Part 6 concludes the study.

\section{Literature Review}

After Modigliani and Miller's (1958) "irrelevance theory of capital structure", the capital structure theory has been a study of interest to finance economists. Extensive researches have been performed to investigate the relationship between capital structure and firms' performance in different countries while Bangladesh has very little contribution in the literature. Firms' behavior in developed countries could differ from that in developing countries. Since Bangladesh is a developing country, it would be logical to discuss previous works from developing countries.

Some authors got positive relationship; some got negative relationship while others got mixed or no relationship between capital structure and firm's performance. Some of the major contributions in the literature on this topic have been discussed in the below.

Roden and Lewellen (1995) employed a sample of 48 U.S. firms during 1981-1990 and found a positive relation between profitability and capital structure. Analogous results were also observed by Champion (1999), Ghosh, Nag, and Sirmans (2000), Hadlock and James (2002). They all concluded that firms with highly profitable firms use high-level of debts.

Margaritis and Psillaki (2010) observed a significant positive relation between leverage and firm's performance. They used a sample of both low and high growth French firms for the period 2003-2005 and found that leverage have positive effect on firms' efficiency over the entire sample.

Using panel data consisting of 257 South African firms over the period 1998 to 2009, Samuel (2013) investigated the association between capital structure and firm performance. To test the relationship, he used GMM regression approach and found a positive and significant relation between financial leverage and firm's performance. Aliakbar, Seyed and Pejman (2013) also found a significant positive link between capital structure and firm performance in the Tehran Stock Exchange.

In contrast, a rigorous study was performed by Rajan and Zingales (1995) to investigate the capital structure of 
48 from the U.S. during the period 1981-1990. Result of that study revealed that there is a negative relation between profitability and debt-level, and the relationship would be more visible if firm size gets bigger. They also added that if return on stock and investments are fixed in a short term, and the main way of external financing is debt, there is a negative correlation between performance and leverage.

Gleason, Lynette, and Ike (2000) concluded that high levels of debt in the capital structure would reduce the firm's performance. They observed that firm's capital structure has a statistically significant negative effect on firm's performance matrixes, i.e., return on assets (ROA), growth in sales (Gsales), and pretax income (Ptax).

A negative link between capital structure and firm's performance was also witnessed by Fama and French (2002). They observed that highly profitable firms with lower risk of financial distress are actually less levered which contradicts with the trade-off theory.

Nor and Fatihah (2012) tried to explore the impact of debt and equity financing on the performance of the firms listed in Bursa Malaysia. Using a sample of 130 firms for the period 2001-2010 combined with multiple regression analysis, they cited a statistical significant negative relation between capital structure and firms' performance.

Manawaduge, Zoysa, Chowdhury, and Chandarakumara (2011) concluded that most of the Sri Lankan firms employ short-term debt capital as against the long-term debt and firm performance is negatively affected by the use of debt. Similar result was also noticed in Nigeria by Amos and Jeremiah (2013). In addition, they documented that firms use retained earnings first, then debts and finally equity.

With cross sectional tie series fixed effect model, Anup and Suman (2010) examined the link between capital structure and firm value in Bangladesh. They found that maximizing the wealth of shareholders demands a perfect mixture of debt and equity, whereas cost of capital has a negative correlation in this choice and it has to be as least as possible. Khairul (2013) also witnessed significant negative relation between profitability and leverage in Bangladeshi firms.

However, some authors revealed mixed results. In this line, Kinsman and Newman (1998) studied the relationship between debt level (including three measures of debt level) and firm's performance and detected diverse results. This study found that earnings are negatively correlated with short-term debt, but are positive with long-term debt. A similar result was found by Mesquita and Lara (2003) in Brazil.

Tianyu (2013) examined the influence of capital structure on firm's performance in both developed and developing markets. A sample of 1200 listed firms in Germany and Sweden and 1000 listed firms in China for the period 2003-2012 has been used in his study. Applying OLS regression method, he documented that capital structure has a significant negative effect on firm's performance in China, whereas, significant positive effect in two European countries, i.e., Germany and Sweden, before financial crisi in 2008.

Using a sample of 237 Malaysian companies during 1995-2011, Salim and Yadav (2012) studied the relationship between capital structure and firm performance. Their analysis revealed that firm performance measured by ROA, ROE and EPS have negative relationship with the capital structure while Tobin's Q has significantly positive relationship with STD and LTD. Similar result was observed by Zeitun and Tian (2007) in their study for a sample of 167 Jordanian companies during 1989-2003.

Ali and Iman (2011) observed that firm's performance, calculated by EPS and Tobin's Q, is positively related with the capital structure, while they got a negative relation between capital structure and ROA. However, they witnessed no significant relationship between ROE and capital structure. Same result was also found by Ebrati, Farzad, Reza, and Ghorban (2013).

Abor (2005) also investigated the link between capital structure and profitability of firms listed in Ghana Stock Exchange for the period 1998-2002. Using regression analysis, he witnessed a significantly positive relation among ROE and the short-term debt and total debt ratio, while, a negative relation with long-term debt.

Conversely, some researchers observed weak to no relation. Phillips and Sipahioglu (2004) documented no significant link between capital structure and firm's performance for publicly traded UK lodging firms; lodging firms seem to prefer external sources as capital return is at a low level.

Ibrahim (2009) also examined the influence of capital-structure choice on firm performance in Egypt. His study based on a sample of non-financial listed firms for the period 1997 to 2005 and used multiple regression analysis. Results suggested that firm performance has weak to no relationship with capital structure choice. Likewise, Khalaf (2013) also found negative and insignificant relationship between short-term and long-term debt ratio, and ROA and profit margin. 


\section{Data and Methodology}

\subsection{Data and Sample}

In developing countries like Bangladesh, to collect data is a troublesome task. Our study mainly considers firms listed in Dhaka Stock Exchange (DSE). Total 254 companies from different sectors are listed in DSE till October, 2013. We exclude all financial institutions, banks and insurance companies from our sample due to their different capital structures and operations. We also exclude newly listed firms. Further we have to eliminate some more firms due to unavailability of data. Finally, our sample consists of 36 firms mostly come from cement, food, fuel \& power, Pharmaceuticals and miscellaneous sectors. These firms are observed over 2007-2012 periods, allowing us to form a canister of panel data of 216 observations. All data are amassed from secondary sources; i.e. annual reports of the sample firms.

\subsection{Variables}

The goal of this study is to examine the influence of capital structure on firm's performance. In this study, four dependent variables; i.e. earnings per share (EPS), return on equity (ROE), return on asset (ROA) and Tobin's Q are used as the representative of firm's performance measures. EPS is the most fundamental of a firm's performance measures which is calculated as net profit after tax divided by number of shares outstanding. ROE is an important profitability ratio that is defined as net profit after tax divided by total equity. ROA is calculated as net profit after tax divided by total assets. Tobin's Q is a popular performance measure which was introduced by James Tobin in 1969 and is defined as total market value of the firm divided by the book value of total assets of the firm.

On the other hand, three independent variables; i.e. the ratio of short-term debt to total assets (STDTA), ratio of long-term debt to total assets (LTDTA) and the ratio of total debt to total assets (TDTA) are employed as the representative of capital structure. In addition, size of the firm (Size) which is determined by logarithm of total assets is also considered as controlled variable.

\subsection{Model}

To investigate the influence of capital structure on firm's performance, this study uses pooling panel data regression models. The basic pooling panel data ordinary least square (OLS) regression model is given in the below:

Here, $\mathrm{i}=1,2, \ldots, \mathrm{N} ; \mathrm{t}=1,2, \ldots, \mathrm{T}$

Where; $Y_{i t}$ is the dependent variable (firm's performance) of firm $i$ in period t. Xit is the independent variable (capital structure) of firm i in period t. $\beta$ is the regression coefficient and $\varepsilon i t$ is the error term.

In panel data analysis, many authors used only pooled ordinary least square (OLS) estimation model. But, the problem with this model is its failure to control for time-invariant firm specific heterogeneity i.e. unobserved fixed effect. Therefore, the model may produce partial and biased results. On the other hand, fixed effects model has also limitation as it assumes that each cross-section's intercept does not vary across time. Since, each of the pooling models has limitations, it would not be correct to use only one model. However, in this study we have used three different pooling models; i.e. pooled OLS model, fixed effects model and random effects model.

To facilitate the choice of suitable pooling models, we used F-test and Hausman test. At first, we run F-test to choose between pooled and fixed effects models. After that, Hausman test are applied to select between a fixed or random effects specification. To test heteroskedasticity in the model, White's test and Wald test are employed. Durbin Watson statistic is also used to test autocorrelation in the regression model. Moreover, to test the stationary of all the variables, Levin, Lin and Chu (2002) test is employed.

Nonetheless, using the following regression models, this study will examine the influence of capital structure choice on firm's performance:

$$
\begin{gathered}
E P S_{i t}=\alpha_{i t}+\operatorname{STDTA}_{i t} \beta 0+\text { Size }_{i t} \beta 1+\varepsilon_{i t} \\
E P S_{i t}=\alpha_{i t}+\text { LTDTA }_{i t} \beta 0+\text { Size }_{i t} \beta 1+\varepsilon_{i t} \\
E P S i t=\alpha_{i t}+T D T A_{i t} \beta 0+\text { Size }_{i t} \beta 1+\varepsilon_{i t} \\
R O E_{i t}=\alpha_{i t}+S T D T A_{i t} \beta 0+\text { Size }_{i t} \beta 1+\varepsilon_{i t} \\
R O E_{i t}=\alpha_{i t}+\text { LTDTA }_{i t} \beta 0+\text { Size }_{i t} \beta 1+\varepsilon_{i t} \\
R O E_{i t}=\alpha_{i t}+T^{\prime} D T A_{i t} \beta 0+\text { Size }_{i t} \beta 1+\varepsilon_{i t}
\end{gathered}
$$




$$
\begin{gathered}
R O A_{i t}=\alpha_{i t}+\text { STDTA }_{i t} \beta 0+\text { Size }_{i t} \beta 1+\varepsilon_{i t} \\
R O A_{i t}=\alpha_{i t}+\text { LTDTA }_{i t} \beta 0+\text { Size }_{i t} \beta 1+\varepsilon_{i t} \\
\text { ROA } A_{i t}=\alpha_{i t}+\text { TDTA }_{i t} \beta 0+\text { Size }_{i t} \beta 1+\varepsilon_{i t} \\
\text { Tobin's } Q_{i t}=\alpha_{i t}+\text { STDTA }_{i t} \beta 0+\text { Size }_{i t} \beta 1+\varepsilon_{i t} \\
\text { Tobin's } Q_{i t}=\alpha_{i t}+\text { LTDTA }_{i t} \beta 0+\text { Size }_{i t} \beta 1+\varepsilon_{i t} \\
\text { Tobin's } Q_{i t}=\alpha_{i t}+\text { TDTA }_{i t} \beta 0+\text { Size }_{i t} \beta 1+\varepsilon_{i t}
\end{gathered}
$$

Where, $\mathrm{EPS}_{\mathrm{it}}$ (Earning per share), $\mathrm{ROE}_{\mathrm{it}}$ (Return on equity), ROA $\mathrm{i}_{\mathrm{it}}$ (Return on asset), and Tobin's $\mathrm{Q}_{\mathrm{it}}$ are financial performance indicators for firm $i$ in year $t$. STDTA $\mathrm{it}_{\mathrm{it}}, \mathrm{LTDTA}_{\mathrm{it}}$ and $\mathrm{TDTA}_{\mathrm{it}}$ indicate short-term debt, long-term debt and total debt to total asset ratios for firm $i$ in year $t$, respectively. Size it $_{\text {d }}$ denotes natural logarithm of total assets for firm $i$ in year $t$ which is a controlled variable in the models. And $\alpha, \beta_{0}$ and $\beta_{1}$ are regression coefficients and $\varepsilon_{\mathrm{it}}$ is the error term. However, Microsoft Excel and Gretl software were used to perform all the statistical computations necessary for this study.

\section{Result Analysis}

\subsection{Descriptive Statistics}

Table 1 presents a summary of descriptive statistics of the dependent and independent variables used in this study. This table mainly shows mean, high, low value, standard deviation and unit root test (LLC) of the variables and provides a general overview of the characteristics of the data. It is interesting that all the variables have positive mean. However, the mean EPS, ROE and ROA are 9.44, 0.13 and 0.07 respectively which reveal that the Bangladeshi firms have very poor return or performance during the sample period, i.e., 2007-2012. Since the inflation rate in Bangladesh was very high; around $8 \%$ during last several years, the real rate of return would be lesser. The Mean of the Tobin's Q is 1.68 which is greater than one implying that the market value of listed companies in Dhaka stock exchange is more than their book values. This indicates that additional investment is needed for the firms since the profits generated are higher than the cost of using the assets of the firms. On the other hand, the mean of the STDTA, LTDTA and TDTA are 40.36, 16.29 and 56.65 percent respectively which indicate that most of the Bangladeshi companies are highly levered. Moreover, they heavily depend on short term debt which is a risky mode of finance for a firm. Finally, the results of the LLC test propose that all the variables do not have unit root; i.e., all the variables are stationary.

Table 1. Descripted statistics

\begin{tabular}{lllllllll}
\hline & EPS & ROE & ROA & Tobin's Q & STD & LTD & TD & SIZE \\
\hline Mean & 9.4378 & 0.1281 & 0.0649 & 1.6825 & 0.4036 & 0.1629 & 0.5665 & 9.3644 \\
Median & 5.0000 & 0.1333 & 0.0456 & 1.2991 & 0.3940 & 0.1068 & 0.5729 & 9.2350 \\
Minimum & $(5.8000)$ & $(3.5000)$ & $(0.1656)$ & 0.0958 & 0.0432 & 0.0003 & 0.1748 & 7.9076 \\
Standard & 10.9680 & 0.3441 & 0.0671 & 1.4274 & 0.2267 & 0.1691 & 0.2252 & 0.6936 \\
Deviation & & & & & & & & \\
Skewness & 1.5223 & $(4.6551)$ & 0.5933 & 1.9821 & 0.6371 & 1.4665 & 0.3924 & 0.3868 \\
Kurtosis & 1.6625 & 60.2020 & 0.9692 & 6.1662 & $(0.0794)$ & 1.5203 & $(0.4520)$ & $(0.6703)$ \\
Observations & 216 & 216 & 216 & 216 & 216 & 216 & 216 & 216 \\
Unit Root test: & $-9.3161 *$ & $-8.2177^{*}$ & $-6.1087^{*}$ & $-4.9077^{*}$ & $-4.3008^{*}$ & $-5.9447 *$ & $-7.7274^{*}$ & $-4.6396^{*}$ \\
LLC Test & & & & & & & & \\
\hline
\end{tabular}

Note. *Significant at the 0.01 level.

\subsection{Regression Analysis}

To examine the relationship between firm performance and capital structure, we have developed twelve distinct regression models in earlier section. Using Gretl we have first carried out panel ordinary least square regression analysis for each twelve models where Gretl facilitate the panel diagnosis. The panel diagnosis helps us to make a choice among pooled, fixed effects and random effects models using F-test and Hausman test. The panel diagnosis suggested for fixed effects model over other models. Therefore, all the regression models were based on the fixed effect models. Furthermore, all the models were tested for heteroskedasticity using White's test and Wald test; and found no heteroskedasticity.

Table 2 shows the results for Models 1 to 3 which examined the relationship between EPS and capital structure 
ratios. The results show that EPS has significant positive relation with STDTA at 5\% level where significant negative relation with LTDTA at $1 \%$ level. But, EPS has insignificant negative relation with TDTA. All models have very high adjusted $\mathrm{R}^{2}$ (75.11, 76.36 and 74.35 percent respectively) indicating the ability of the models explaining the variation of EPS due to variation of independent variables (debt levels and size) is very high. The F-value shows that the explanatory variables are jointly statistically significant in the model and the Durbin-Watson (DW) statistics reveals that there is no autocorrelation in the models. In addition, EPS has no significant relation with the control variable; firm size at 5\% level. The finding for STDTA is consistent with Ali and Iman (2011), Hadlock and James (2002) and Suleiman (2013) while the finding for LTDTA is consistent with Rajan and Zingales (1995), Suleiman (2013). And the finding for TDTA is consistent with Salteh, Ghanavati, Khanqah, and Khosroshahi (2012).

Table 2. Relations between EPS and debt levels

\begin{tabular}{|c|c|c|c|c|}
\hline Models & Fixed Effects Model & & & \\
\hline & & Coefficient & T-ratio & P-value \\
\hline \multirow[t]{6}{*}{ Model 1} & Const & -36.6287 & -1.601 & 0.1111 \\
\hline & STDTA & 10.8613 & 2.389 & $0.0179 * *$ \\
\hline & Size & 4.45119 & 1.884 & $0.0612 *$ \\
\hline & Adj $R^{2}$ & & 0.7511 & \\
\hline & F-Value & & $18.5378^{* * *}$ & \\
\hline & Durbin-Watson & & 2.9351 & \\
\hline \multirow[t]{6}{*}{ Model 2} & Const & 15.3346 & 0.7224 & 0.471 \\
\hline & STDTA & -22.7194 & -3.921 & $0.0001 * * *$ \\
\hline & Size & -0.234605 & -0.105 & 0.9165 \\
\hline & Adj $R^{2}$ & & 0.7636 & \\
\hline & F-Value & & $19.7664 * * *$ & \\
\hline & Durbin-Watson & & 2.1236 & 0.8449 \\
\hline \multirow[t]{6}{*}{ Model 3} & Const & -5.03198 & -0.1959 & 0.6197 \\
\hline & STDTA & -2.16679 & -0.4971 & 0.5195 \\
\hline & Size & 1.67627 & 0.6454 & \\
\hline & Adj $R^{2}$ & & 0.7435 & \\
\hline & F-Value & & $17.8438^{* * *}$ & \\
\hline & Durbin-Watson & & 1.5361 & \\
\hline
\end{tabular}

Note. * significant at $0.10, * *$ significant at 0.05 and $* * *$ significant at 0.01 level.

Table 3 represents the results for models 4 to 6 which investigated the relationship between ROE and capital structure ratios. The results indicate that there are negative correlation between ROE and debt levels (STDTA, LTDTA and TDTA), but is not significant at $10 \%$ level of significance. Low value of adjusted $\mathrm{R}^{2}(12.82,12.72$ and 12.84 percent respectively) is observed. From the DW statistics no autocorrelation is observed. The results are consistent with Zeitun and Tian (2007), Ebaid (2009) and Ali and Iman (2011). 
Table 3. Relations between ROE and debt levels

\begin{tabular}{|c|c|c|c|c|}
\hline Models & Fixed Effects Model & & & \\
\hline & & Coefficient & T-ratio & $\mathrm{P}$-value \\
\hline \multirow[t]{6}{*}{ Model 4} & Const & 1.0348 & 0.7705 & 0.4420 \\
\hline & STDTA & -0.1256 & -0.4705 & 0.6386 \\
\hline & Size & -0.0914 & -0.6590 & 0.5107 \\
\hline & Adj $R^{2}$ & & 0.1282 & \\
\hline & F-Value & & $1.8546^{* * *}$ & \\
\hline & Durbin-Watson & & 2.4728 & \\
\hline \multirow[t]{6}{*}{ Model 5} & Const & 0.7967 & 0.6226 & 0.5343 \\
\hline & STDTA & -0.0333 & -0.0953 & 0.9241 \\
\hline & Size & -0.0708 & -0.5257 & 0.5998 \\
\hline & Adj $R^{2}$ & & 0.1272 & \\
\hline & F-Value & & $1.8467 * * *$ & \\
\hline & Durbin-Watson & & 2.4708 & \\
\hline \multirow[t]{6}{*}{ Model 6} & Const & 1.2016 & 0.8089 & 0.4197 \\
\hline & STDTA & -0.1293 & -0.5131 & 0.6085 \\
\hline & Size & -0.1068 & -0.7111 & 0.4780 \\
\hline & $\operatorname{Adj} R^{2}$ & & 0.1284 & \\
\hline & F-Value & & $1.8562 * * *$ & \\
\hline & Durbin-Watson & & 2.4764 & \\
\hline
\end{tabular}

Note. $*$ significant at $0.10,{ }^{* *}$ significant at 0.05 and $* * *$ significant at 0.01 level.

Table 4 shows the results for models 7 to 9 which test the relationship between ROA and capital structure ratios. The results confirm that ROA has significant negative relation with STDTA at $10 \%$ level and with LTDTA and TDTA at $1 \%$ level. High adjusted $\mathrm{R}^{2}(71.63,72.37$ and 73.34 percent respectively) is found. The F-value for all models is also significant at $1 \%$ level. The control variable; size has negative relation with ROA in all models, but not significant in models 7 and 8 while significant in model 9 at $5 \%$ level. DW statistics reveals that there is no autocorrelation in the models. These results are consistent with Rajan and Zingales (1995), Gleason et al. (2000), Manawaduge et al. (2011), Ali and Iman (2011), Salim and Yadav (2012), Anup and Suman (2010) and Nor and Fatihah (2012) who found a significant negative relationship between capital structure and firm's performance.

Table 4. Relations between ROA and debt levels

\begin{tabular}{lllll}
\hline Models & Fixed Effects Model & & & \\
\hline Model 7 & & Coefficient & T-ratio & P-value \\
& Const & 0.2513 & 1.6810 & $0.0945^{*}$ \\
& STDTA & -0.0538 & -1.8140 & $0.0714^{*}$ \\
& Size & -0.0175 & -1.1390 & 0.2563 \\
& Adj R & & \\
& F-Value & & 0.7163 & $15.6749^{* * *}$ \\
\hline Model 8 & Durbin-Watson & & 2.3902 & $0.0603^{*}$ \\
& Const & & 1.8900 & $0.0049^{* * *}$ \\
& STDTA & 0.2654 & -2.8510 & 0.1880 \\
\hline
\end{tabular}




\begin{tabular}{|c|c|c|c|c|}
\hline & Adj $R^{2}$ & & 0.7237 & \\
\hline & F-Value & & $16.2215 * * *$ & \\
\hline & Durbin-Watson & & 2.4350 & \\
\hline \multirow[t]{6}{*}{ Model 9} & Const & 0.4935 & 3.0800 & $0.0024 * * *$ \\
\hline & STDTA & -0.1050 & -3.8620 & $0.0002 * * *$ \\
\hline & Size & -0.0394 & -2.4320 & $0.016 * *$ \\
\hline & Adj $R^{2}$ & & 0.7334 & \\
\hline & F-Value & & $16.9889^{* * *}$ & \\
\hline & Durbin-Watson & & 2.4298 & \\
\hline
\end{tabular}

Note. $*$ significant at $0.10, * *$ significant at 0.05 and $* * *$ significant at 0.01 level.

Table 5 represents the results for models 10 to 12 which investigate the influence of capital structure on the Tobin's Q. The results show insignificant positive relation between Tobin's Q and STDTA and TDTA at 10\% levels whereas insignificant negative relation exists between Tobin's Q and LTDTA at 10\% level. The size has also insignificant negative relation with Tobin's Q. According to DW statistics, there is no autocorrelation in the models. These results are also consistent with Zeitun and Tian (2007), Abor (2007), Salteh, et al. (2012) and Ebrati et al. (2013).

Table 5. Relations between Tobin's Q and debt levels

\begin{tabular}{|c|c|c|c|c|}
\hline Models & Fixed Effects Model & & & \\
\hline & & Coefficient & T-ratio & P-value \\
\hline \multirow[t]{6}{*}{ Model 10} & Const & 4.4296 & 1.1000 & 0.2728 \\
\hline & STDTA & 0.4426 & 0.5530 & 0.5809 \\
\hline & Size & -0.3124 & -0.7512 & 0.4535 \\
\hline & Adj $R^{2}$ & & 0.5447 & \\
\hline & F-Value & & $7.9509^{* * *}$ & \\
\hline & Durbin-Watson & & 2.4731 & \\
\hline \multirow[t]{6}{*}{ Model 11} & Const & 7.0231 & 1.8380 & $0.0677^{*}$ \\
\hline & STDTA & -1.3144 & -1.2610 & 0.2091 \\
\hline & Size & -0.5474 & -1.3610 & 0.1752 \\
\hline & Adj $R^{2}$ & & 0.5479 & \\
\hline & F-Value & & $8.0427 * * *$ & \\
\hline & Durbin-Watson & & 2.4541 & \\
\hline \multirow[t]{6}{*}{ Model 12} & Const & 6.4141 & 1.4390 & 0.1518 \\
\hline & STDTA & 0.2906 & -0.3843 & 0.7012 \\
\hline & Size & -0.4877 & -1.0820 & 0.2805 \\
\hline & Adj $R^{2}$ & & 0.5443 & \\
\hline & F-Value & & $7.9395^{* * *}$ & \\
\hline & Durbin-Watson & & 2.4408 & \\
\hline
\end{tabular}

Note. * significant at $0.10, * *$ significant at 0.05 and $* * *$ significant at 0.01 level.

\section{Conclusions}

This study aims to examine the influence of capital structure on firm's performance using a sample of 36 Bangladeshi firms for the period 2007-2012. The results of this study reveal that the firm's performance as calculated by EPS is significantly positively linked to capital structure as measured by STDTA. In contrast, EPS is significantly negatively related to LTDTA while EPS has insignificant relation with TDTA. This study also finds no statistically significant relationship between ROE and capital structure.

On the other hand, statistically very significant relationship exists between ROA and capital structure; i.e. ROA has significant negative relation with all debt levels (STDTA, LTDTA \& TDTA). Lastly, our findings indicate that there is no statistically significant relation between Tobin's Q and capital structure. It is also observed that 
the controlled variable; firm size has positive impact on EPS and negative impact on ROA. Another important observation is that LTDTA has negative impact on all the measures (EPS, ROE, ROA and Tobin's Q) of firm's performance. With the exception of the positive relation between EPS and STDTA, we can conclude that capital structure has negative impact on firm's performance. That is, the more the debts incorporate in the capital structure, the less the firm's performance and vice versa. Even though, these findings are in contrast to trade-off theory, this is consistent with the proposition of Pecking Order Theory as developed by Myers and Majluf (1984). Various popular studies such as Harris and Raviv (1991), Rajan and Zingales (1995), Fama and French (2002), Gleason, Lynette, and Ike (2000), Booth, Aivazian, Demirguc-Kunt, and Maksimovic (2001), Manawaduge at el (2011) and Anup and Suman (2010) also support this negative relationship.

Nonetheless, this negative relationship can be explained by the higher cost of debt and strong covenants attach to the use of debt due to underdeveloped equity and debts (long-term) markets in Bangladesh. In addition, our results also suggest that the finance managers should use debts as last alternative in their capital structure. To the end, our study can be extended by incorporating more controlled variables, larger sample and longer period data in the regression models to get better results. Other measures and methodology can also be employed.

\section{References}

Abor, J. (2005). The effect of capital structure on profitability: An empirical analysis of listed firms in Ghana. Journal of Risk Finance, 6(5), 438-447. http://dx.doi.org/10.1108/15265940510633505

Aliakbar, R., Seyed, H. S. N., \& Pejman, M. (2013). The relationship between capital structure decisions with firm performance: Comparison between big and small industries in firms listed at Tehran Stock Exchange. World of Sciences Journal, 1(9), 83-92.

Alom, K. (2013). Capital structure choice of Bangladeshi firms: An empirical investigation. Asian Journal of Finance \& Accounting, 5(1), 320-333.

Al-Taani, K. (2013). The relationship between capital structure and firm performance: Evidence from Jordan. Journal of Finance and Accounting, 1(3), 41-45.

Arowoshegbe, A. O. \& Idialu, J. O. (2013). Capital structure and profitability of quoted companies in Nigeria. International Journal of Business and Social Research, 3(3), 99-106.

Baker, M. \& Wurgler, J. (2002). Market timing and capital structure. Journal of Finance, 57(1), 1-32. http://dx.doi.org/10.1111/1540-6261.00414

Booth, L., Aivazian, V., Demirguc-Kunt, A., \& Maksimovic, V. (2001). Capital structure in developing countries. Journal of Finance, 56(1), 87-130. http://dx.doi.org/10.1111/0022-1082.00320

Champion, D. (1999). Finance: The joy of leverage. Harvard Business Review, 77(4), 19-22.

Chowdhury, A., \& Chowdhury, S. P. (2010). Impact of capital structure on firm's value: Evidence from Bangladesh. Business and Economic Horizons, 3(3), 111-122. http://dx.doi.org/10.15208/beh.2010.32

Ebaid, I. E. S. (2009). The impact of capital-structure choice on firm performance: Empirical evidence from Egypt. Journal of Risk Finance, 10(5), 477-487. http://dx.doi.org/10.1108/15265940911001385

Ebrati, R. M., Farzad, E., Reza, S. B., \& Ghorban, S. (2013). The impact of capital structure on firm performance: Evidence from Tehran Stock Exchange. Australian Journal of Basic \& Applied Sciences, 7(4), $1-8$.

Fama, E. F., \& French, K. R. (2002). Testing trade-off and pecking order prediction, about dividends and debt. Review of Financial Studies, 15(1), 1-33. http://dx.doi.org/10.1093/rfs/15.1.1

Fosu, S. (2013). Capital structure, product market competition and firm performance: Evidence from South Africa. The Quarterly Review of Economics and Finance, 53(2), 140-151. http://dx.doi.org/10.1016/j.qref.2013.02.004

Ghosh, C., Nag, R., \& Sirmans, C. (2000). The pricing of seasoned equity offerings: evidence from REITs. Real Estate Economics, 28(3), 363-84. http://dx.doi.org/10.1111/1540-6229.00805

Gitman, L. J., \& Zutter, C. J. (2010). Principles of managerial finance (13th ed.). New York: Prentice Hall.

Gleason, K. C., Lynette, K M., \& Ike, M. (2000). The Interrelationship between culture, capital structure, and performance: Evidence from European retailers. Journal of Business Research, 50(2), 185-191. http://dx.doi.org/10.1016/S0148-2963(99)00031-4

Hadlock, C., \& James, C. (2002). Do banks provide financial slack? Journal of Finance, 57(3), 1383-420. 
Harris, M., \& Raviv, A. (1991). The theory of capital structure. Journal of Finance, 46(1), 297. http://dx.doi.org/10.1111/j.1540-6261.1991.tb03753.x

Kinsman, M., \& Newman, J. (1998). Debt tied to lower firm performance: Finding calls for review of rise in debt use. Graziadio Business Review, 1(3).

Jensen, M. C., \& Meckling, W. H. (1976). Theory of the firm: Managerial behavior, agency costs and ownership $\begin{array}{lllll}\text { structure. Journal of } & \text { Financial 305-360. }\end{array}$ http://dx.doi.org/10.1016/0304-405X(76)90026-X

Manawaduge, A., Zoysa, A. D., Chowdhury, K., \& Chandarakumara, A. (2011). Capital structure and firm performance in emerging economies: An empirical analysis of Sri Lankan firms. Corporate Ownership \& Control, 8(4), 253-263.

Margaritis, D., \& Psillaki, M. (2010). Capital structure, equity ownership and firm performance. Journal of Banking \& Finance, 34(3), 621-632. http://dx.doi.org/10.1016/j.jbankfin.2009.08.023

Mesquita, J. M. C., \& Lara, J. E. (2003). Capital Structure and Profitability: The Brazilian case. Academy of business \& administration sciences conference, Vancouver.

Modigliani, F., \& Miller, M. H. (1958). The cost of capital, corporation finance, and the theory of investment. American Economic Review, 48(3), 261-297.

Modigliani, F., \& Miller, M. H. (1963). Corporate income taxes and the cost of capital: A correction. American Economic Review, 53(3), 443-453.

Mohamad, N. E. A. B., \& Abdullah, F. N. B. A. (2012). Reviewing relationship between capital structure and firm's performance in Malaysia. International Journal of Advances in Management and Economics, 1(4), $151-156$.

Mumtaz, R., Rauf, S. A., Bashir, A., \& Noreen, U. (2013). Capital structure and financial performance: Evidence from Pakistan (Kse 100 Index). Journal of Basic and Applied Scientific Research, 3(4), 113-119.

Myers, S. C., \& Majluf, N. S. (1984). Corporate financing and investment decisions when firms have information that investors do not have. Journal of Financial Economics, 13(2), 187-221. http://dx.doi.org/10.1016/0304-405X(84)90023-0

Phillips, P., \& Sipahioglu, M. (2004). Performance implications of capital structure: Evidence from quoted UK organizations with hotel interests. The Service Industries Journal, 24(5), 31-51. http://dx.doi.org/10.1080/0264206042000276829

Rajan, R. G., \& Zingales, L. (1995). What do we know about capital structure? Some evidence from international data. Journal of Finance, 50(5), 1421-1460. http://dx.doi.org/10.1111/j.1540-6261.1995.tb05184.x

Roden, D., \& Lewellen, W. (1995). Corporate capital structure decisions: Evidence from leveraged buyouts. Financial Management, 24(2), 76-87. http://dx.doi.org/10.2307/3665536

Saeedi, A., \& Mahmoodi, I. (2011). Capital Structure and firm performance: Evidence from Iranian companies. International Research Journal of Finance and Economics, 70, 20-29.

Salim, M., \& Yadev, R. (2012). Capital structure and firm performance: Evidence from Malaysian listed companies. Social and Behavioral Sciences, 65, 156-166.

Salteh, H. M., Ghanavati, E., Khanqah, V. T., \& Khosroshahi, M. A. (2012). Capital structure and firm performance; Evidence from Tehran Stock Exchange. International Proceedings of Economics Development \& Research, 43, 225-230.

Suleiman A. (2013). Capital structure effect on firms'performance: Evidence from Saudi listed companies. Saint Mary's University, Master's thesis. Retrieved from http://library2.smu.ca/bitstream/handle/01/25264/alawwad_suleiman_mrp_2013.pdf?sequence=1

Tianyu, H. (2013). The comparison of impact from capital structure to corporate performance between Chinese and European listed firms. Master's thesis of Jonkoping University. Retrieved from http://urn.kb.se/resolve?urn=urn:nbn:se:hj:diva-21994

Umar, M., Tanveer, Z., Aslam, S., \& Sajid, M. (2012). Impact of capital structure on firms' financial performance: Evidence from Pakistan. Research Journal of Finance and Accounting, 3(9), 1-12.

Van Horne, J., \& Wachowicz, J. (1995). Fundamentals of financial management (9th ed.). New Jersey: Prentice 
Hall.

Weston, J. F., \& Brigham, E. F. (1979). Managerial finance. Holt, Rinehart and Winston.

Zeitun, R., \& Tian, G. G. (2007). Capital structure and corporate performance: Evidence from Jordan. The Australasian Accounting Business and Finance Journal, 1(4), 40-61.

\section{Copyrights}

Copyright for this article is retained by the author(s), with first publication rights granted to the journal.

This is an open-access article distributed under the terms and conditions of the Creative Commons Attribution license (http://creativecommons.org/licenses/by/3.0/). 